\title{
Why Consumers are Hesitant to Shop Online: The Major Concerns towards Online Shopping
}

Nurul Nadia Abd Aziz, Normilia Abd Wahid

To Link this Article: http://dx.doi.org/10.6007/IJARBSS/v8-i9/4689

DOI: $\quad 10.6007 /$ IJARBSS/v8-

i9/4689

Received: 13 August 2018, Revised: 07 Sept 2018, Accepted: 21 Sept 2018

Published Online: 11 October 2018

In-Text Citation: (Aziz \& Wahid, 2018)

To Cite this Article: Aziz, N. N. A., \& Wahid, N. A. (2018). Why Consumers are Hesitant to Shop Online: The Major Concerns towards Online Shopping. International Journal of Academic Research in Business and Social Sciences, 8(9), 1175-1185.

\section{Copyright: (C) 2018 The Author(s)}

Published by Human Resource Management Academic Research Society (www.hrmars.com) This article is published under the Creative Commons Attribution (CC BY 4.0) license. Anyone may reproduce, distribute, translate and create derivative works of this article (for both commercial and non-commercial purposes), subject to full attribution to the original publication and authors. The full terms of this license may be seen at: http://creativecommons.org/licences/by/4.0/legalcode

Vol. 8, No. 9, September 2018, Pg. 1175 - 1185 


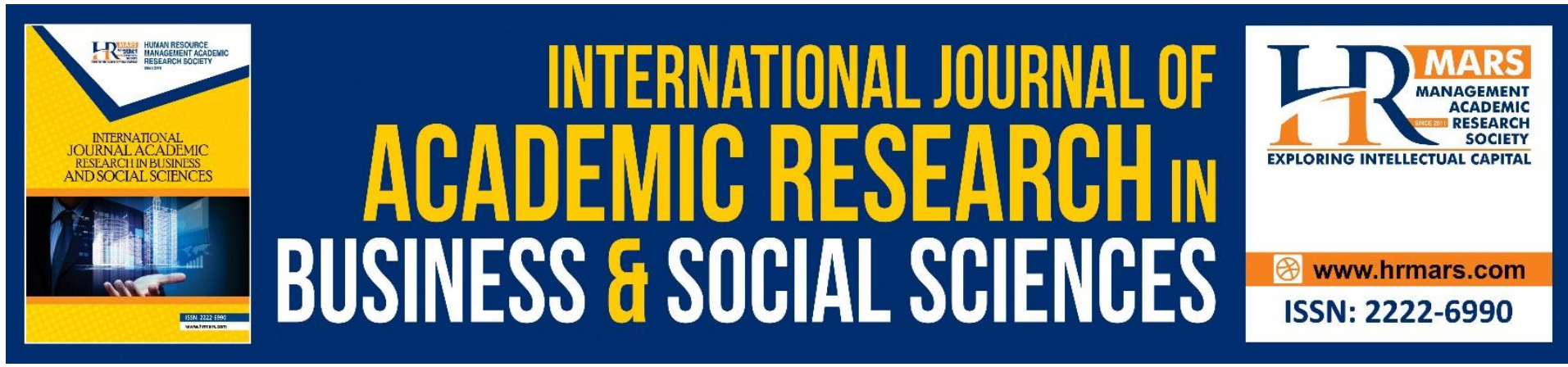

\title{
Why Consumers are Hesitant to Shop Online: The Major Concerns towards Online Shopping
}

\author{
Nurul Nadia Abd Aziz ${ }^{1 *}$, Normilia Abd Wahid ${ }^{2}$ \\ ${ }^{1 *}$ Faculty of Business and Management, Universiti Teknologi MARA Cawangan Pahang \\ Kampus Raub, Malaysia \\ ${ }^{2}$ Faculty of Business and Management, Universiti Teknologi MARA Cawangan Pahang \\ Kampus Jengka, Malaysia
}

\begin{abstract}
Online purchases have become a new trend of shopping among university students in today's Industrial Revolution 4.0. But, not all university students are open to shop online. Therefore, this study aims to explore the major concerns towards online shopping that stops non-online shoppers to purchase online. The study aims to provide the needed information to understand the barriers for university students to shop online. A total number of 154 valid surveys were collected in local universities using convenience sampling. Statistical procedures of descriptive was used to analyze the collected data. The main findings of this study are that non-online shoppers are unlikely to buy online because they prefer to shop traditionally and self-assess the quality of the goods before they buy. This study also discusses the implications of the study to practitioners in which the traditional sellers should provide the comfortable shopping environment, improve the behavior and skills of salespeople, and offer after-sale services to their customers to remain competitive with online vendors.
\end{abstract}

Keywords: Non-Online Shoppers, Perceived Integrity, Perceived Risks, Trust

\section{Introduction}

Online shopping is a form of electronic commerce that allows users to directly purchase goods or services from vendors through the Internet using a web browser. Nowadays, online shopping is becoming popular as the most convenient shopping way especially among the younger generation (Al-maghrabi, Dennis, \& Halliday, 2011; Chakraborty, Lee, Bagchi-Sen, Upadhyaya, \& Raghav Rao, 2016; M. Kumar, 2016; Massad \& Berardelli, 2016) who are directly affected by the Internet explosion. According to statistics by the PayPal payment gateway that handles payment transactions, online purchases have increased three-fold from 2010 to 2015, where the total value of sales in Malaysia surged from RM1.82 billion to RM5.76 billion (Saidi, 2016).

Unlike traditional shopping, online shopping is a convenient way to purchase that allows buyers to get the desired items without having to leave their home, go through the traffic jam, searching for parking, while saving on travelling costs (Akroush \& Al-Debei, 2015; Huseynov \& Yildirim, 2016) by not having to pay for fuel and tolls. In addition, online shopping also saves time (Huseynov \& Yildirim, 2016; Mittal, 2013) because users only need to look in 
search engines such as Yahoo! and Google without having to visit stores or boutiques as well as not having to queue at the counter. Among the other advantages of online shopping is that users can shop from the comfort of their computer or tablet; easier to make a price comparison and avail discounts offered; and shop at any time (Aziz \& Wahid, 2017; 2018; Jadhav \& Khanna, 2016).

The other advantages of using online shopping has been much discussed by previous researchers across the world (Al-maghrabi et al., 2011; Badari \& Hashim, 2015; Irshad, 2016; M. Kumar, 2016; Lim, Osman, Salahuddin, Romle, \& Abdullah, 2016; Nuryakin \& Farida, 2016; Nwaizugbo \& Ifeanyichukwu, 2016; Sharma, 2016; Violani, 2016). Despite many advantages of online purchasing, online shoppers, however, cannot see, touch, or smell the goods before deciding to buy (Al-Debei, Akroush, \& Ashouri, 2015). Therefore, they tend to perceive a higher level of risk. Hence, it can be expected that the bigger the concerns of consumers, the lower the online purchase intention.

Review of previous studies shows that most previous researchers focused on testing the relationship between various factors influencing online shopping behavior (Al-maghrabi et al., 2011; Badari \& Hashim, 2015; Irshad, 2016; M. Kumar, 2016; Lim et al., 2016; Nuryakin \& Farida, 2016; Sharma, 2016; Violani, 2016). However, only few researchers have raised the issues regarding the consumer's concern towards online shopping specifically among university students in Malaysia (P. Kumar \& Bajaj, 2016), which are an important market segment as they grew up with technology causing them to be very sociable, media savvy and tech-literate (Bilgihan, 2016). Few studies have been conducted in this regard in foreign countries (Bay, Cook, Grubisic, \& Nikitkov, 2014; Massad \& Berardelli, 2016; Narayanan, Koo, \& Cozzarin, 2012; Nuryakin \& Farida, 2016; Topalo, 2012; Van Der Meulen, 2013) but their culture may be different from Malaysia.

Hence, this paper intents to fulfil the research gap by exploring the major concerns towards online shopping among university students in Malaysia. Therefore, this study explores the major concerns in online shopping and becoming an obstacle for non-online shoppers to purchase online. Additionally, the findings of prior research only significantly contributed to the online vendors. The current study, however, differs from previous studies as we also discuss the implications of research findings to traditional retailers for which they should utilized their advantages, which are not owned by online vendors, in marketing their products to non-online shoppers.

\section{Literature Review}

Our previous study found that university students still shop online, regardless of whether they received financial support from their parents or not (Aziz \& Wahid, 2017). Among the motivators for university's students to shop online are the trustworthiness of the brand, followed by attractive discount price bids, guarantees (such as money back guarantee for damaged items), privacy statements, and finally a shorter delivery period (Ang \& Lee, 2002). In terms of products that are most purchased online by the university's students include clothes, electronic devices, gifts, sports and dietary supplements (Aziz \& Wahid, 2017).

Some researchers emphasize that fundamental uncertainty regarding risk, privacy and security are very important factors in influencing behavioral intention among non-online shoppers in developing countries (Faqih, 2016). This uncertainty is often considered as trust factor (Al-Debei et al., 2015; Bilgihan, 2016; Chen, Yan, Fan, \& Gordon, 2015; George, Ogunkoya, Lasisi, \& Elumah, 2015). 
Some researchers (Cheung \& Lee, 2003; George et al., 2015) found that perceived risk shows the greatest negative impact on consumer trust in online shopping. In other words, the greater the perceptions of risks in online shopping, the less their trust in online vendors and ultimately consumers may lose interest in getting familiar with online shopping methods. The possible explanation is that consumers cannot physically examine their products before buying. This finding supports the previous research who found that level of trust on online vendors is lower than face-to-face interaction in physical stores (George et al., 2015) because the consumers cannot feel and touch (Al-Debei et al., 2015) the product before purchasing it.

Furthermore, consumers are also concerned about the disclosure of their personal information through transactions with online vendors. This concern refers to the risk of misuse of personal information such as the user's home address, e-mail address, telephone number, and credit or debit card numbers (M. Kumar, 2016; Ling \& Yazdanifard, 2014).This argument is in line with the previous study which found that consumers are willing to purchase online because of their level of trust on vendors (Al-Debei et al., 2015; Bilgihan, 2016; Chen et al., 2015; George et al., 2015). Some researchers found that perceived integrity is a significant antecedent of consumer trust in online shopping (Cheung \& Lee, 2003).

In literature, comparative studies among online shoppers and non-online shoppers contribute significantly to online vendors' implications. Discussions of previous studies focus more on improving the quality of the website, improve marketing strategies for online vendors to attract consumers and make their virtual stores more competitive. Although in the era of the Industrial Revolution 4.0 where online shopping has become a popular trend among $\mathrm{Y}$ and $\mathrm{Z}$ generations, continuous and unconditional support should be given to traditional retailers to ensure they can remain relevant in competition with online vendors. Therefore, this study offers a more comprehensive understanding and better insights of the barriers that hinder the non-online shoppers to purchase online specifically from the view of university students. This knowledge is very important and useful to traditional retailers so they can highlight their advantages over online vendors.

\section{Methodology}

The study is descriptive in nature, and hence, the primary data for the study was collected through a self-administered questionnaire. As this study aims to understand the major concerns towards online shopping among non-online shoppers, a convenience sampling was employed. All the respondents were university students in the age group of 18 to 20 years. They are enrolled in undergraduate courses affiliated with Universiti Teknologi MARA in Malaysia. The total number of respondents was 154 (male $=121$, female $=35)$. The questionnaire consisted of three questions, which are (1) for what reasons you don't prefer shopping online? (2) Which of the following statements is your concerned about online purchases? (3) How often do privacy concerns prevent you from buying products online? The data was analyzed using percentage analysis and descriptive statistics.

\section{Analysis and Results}

A total of 154 questionnaires were returned, giving a $98 \%$ response rate. The sample was, with 121 (78.5\%) male respondents and 35 (22.7\%) female respondents. The study examines why the respondents are hesitant to shop online based on closed ended questions. A cross tabulation was performed to study the behaviours of non-online shoppers. 
INTERNATIONAL JOURNAL OF ACADEMIC RESEARCH IN BUSINESS AND SOCIAL SCIENCES Vol. 8, No. 9, Sept. 2018, E-ISSN: 2222-6990 @ 2018 HRMARS

Table 1: Descriptive Statistics

\begin{tabular}{|l|l|l|l|l|}
\hline & Mean & $\begin{array}{l}\text { Std. } \\
\text { Deviation }\end{array}$ & Skewness & Kurtosis \\
\hline I do not know much about using the Internet. & 1.29 & .456 & .958 & -1.114 \\
\hline I do not know how to shop online. & 1.47 & .502 & .140 & -1.037 \\
\hline I do not have a credit card. & 1.59 & .495 & -.370 & -1.917 \\
\hline I do not have time to shop online. & 1.36 & .482 & .613 & -1.670 \\
\hline $\begin{array}{l}\text { I do not trust to give my credit card and } \\
\text { personal details. }\end{array}$ & 1.67 & .473 & -.744 & -1.487 \\
\hline I never had the opportunity to do so. & 1.25 & .434 & 1.201 & -.575 \\
\hline $\begin{array}{l}\text { I am unsure about how to return faulty } \\
\text { products. }\end{array}$ & 1.45 & .501 & .197 & -1.017 \\
\hline I prefer to visit real shops & 1.79 & .407 & -1.489 & .221 \\
\hline I prefer to be able to examine the physically. & 1.64 & .482 & -.613 & -1.670 \\
\hline $\begin{array}{l}\text { I dislike the idea of shipping charges when } \\
\text { buying on the Internet. }\end{array}$ & 1.37 & .486 & .551 & -1.746 \\
\hline $\begin{array}{l}\text { I dislike the idea of buying goods without } \\
\text { interaction with shop assistants. }\end{array}$ & 1.37 & .486 & .551 & -1.746 \\
\hline Online shopping is too complicated. & 1.52 & .503 & -.084 & -1.050 \\
\hline It is difficult to judge quality of product. & 1.68 & .468 & -.813 & -1.378 \\
\hline Product delivery takes too long. & 1.58 & .498 & -.311 & -1.958 \\
\hline I worry about product quality. & 1.79 & .407 & -.489 & .221 \\
\hline I worry about getting scammed by the seller. & 1.89 & .315 & -.552 & 1.641 \\
\hline I worry about personal privacy. & 1.64 & .482 & -.613 & -1.670 \\
\hline I worry about payment security. & 1.71 & .456 & -.958 & -1.114 \\
\hline $\begin{array}{l}\text { I worry about my credit card number being } \\
\text { stolen on the Internet. }\end{array}$ & 1.67 & .473 & -.744 & -1.487 \\
\hline $\begin{array}{l}\text { How do privacy concerns prevent you from } \\
\text { buying products online? }\end{array}$ & 2.23 & 1.087 & .452 & -1.060 \\
\hline
\end{tabular}

The mean scores, standard deviation, skewness and kurtosis values of the variables were presented in Table 1. The value of each measurement item shows that the skewness value ranging between \pm 2.0 . Hence, with generally accepted criteria, the data is considered to be approximately normal distributed.

Table 2 presents the reason for people do not prefer shopping online. The main reasons are that they prefer to visit real shops (68.6\%). Compared to online shopping, traditional shopping is often a choice for those who like to interact with salespeople, touch the merchandise and try out clothes in the fitting room and enjoy the ambience and experience of going out with friends (Monsuwé, Dellaert, \& Ruyter, 2004). A total of 104 respondents indicate that they do not prefer to use online shopping because it is difficult for them to judge quality of product (66.7\%). This result is consistent with the previous findings that people feel that they might be delivered low quality / unwanted product or fake product though online shopping (Katawetawaraks \& Wang, 2011; Mittal, 2013). Accordingly, they would prefer to touch and feel product before they make a purchase decision and this response can immediately discern the quality of a product. 
INTERNATIONAL JOURNAL OF ACADEMIC RESEARCH IN BUSINESS AND SOCIAL SCIENCES Vol. 8, No. 9, Sept. 2018, E-ISSN: 2222-6990 @ 2018 HRMARS

Table 2: Reason Don't Prefer Shopping Online

\begin{tabular}{|l|l|l|}
\hline For what reason you don't prefer shopping online? & $\begin{array}{l}\text { Frequency } \\
\text { (N=154) }\end{array}$ & . \\
\hline I prefer to visit real shops & 107 & 68.6 \\
\hline It is difficult to judge quality of product & 104 & 66.7 \\
\hline I do not trust to give my credit card and personal details & 91 & 58.3 \\
\hline I do not have a credit card & 89 & 57.1 \\
\hline I prefer to be able to examine the product physically & 86 & 55.1 \\
\hline Product delivery takes too long & 82 & 52.6 \\
\hline I am unsure about how to return faulty products & 69 & 44.2 \\
\hline I do not know how to shop online & 59 & 37.8 \\
\hline Online shopping is too complicated & 58 & 37.2 \\
\hline I dislike the idea of shipping charges when buying on the internet & 51 & 32.7 \\
\hline I dislike the idea of buying goods without interaction with shop assistants & 48 & 30.8 \\
\hline I do not have time to shop online & 42 & 26.9 \\
\hline I never had the opportunity to do so & 34 & 21.8 \\
\hline I do not know much about using the internet & 32 & 20.5 \\
\hline
\end{tabular}

In addition, the other reasons for non-online shoppers do not prefer shop online is they do not trust to give credit card and personal details (58.3\%). This reason is associated with the privacy and security concerns. This result is in line with the findings of other studies that reveal a major reason impede consumers from online shopping is security problem because they are concern about transaction security and data personal (Katawetawaraks \& Wang, 2011; Lian \& Yen, 2013).

Besides, the current study also found that the non-online shoppers do not prefer to use online shopping because they do not have a credit card (57.1\%) and they favour to examine the product physically (55.1\%). Some respondents (52.6\%) said that they not prefer to shop online because product delivery takes too long and this reason is constant with (Dai, Harried, \& Salam, 2011) who revealed that service delivery quality is important antecedent and positively associated with consumer service enjoyment. However, the other more common reasons are they are unsure about how to return faulty products (44.2\%), they do not know how to shop online (37.8\%), and online shopping is too complicated (37.2\%). All these reasons are related with consumer knowledge. These results confirm the previous findings of prior researchers that found internet knowledge and level of education are important predictors in online purchasing among university students (Dhanapal, Vashu, \& Subramaniam, 2015). This in turn explains that although the evolution of e-commerce is an important factor in shaping consumer purchasing behaviour, socioeconomic factors are also seen to contribute to the level of user's internet knowledge (Hernández, Jiménez, \& José Martín, 2011; Nazir, Tayyab, Sajid, Ur Rashid, \& Javed, 2012). 
INTERNATIONAL JOURNAL OF ACADEMIC RESEARCH IN BUSINESS AND SOCIAL SCIENCES Vol. 8, No. 9, Sept. 2018, E-ISSN: 2222-6990 @ 2018 HRMARS

Table 3: Concern about Online Shopping

\begin{tabular}{|l|l|l|}
\hline $\begin{array}{l}\text { Which of the following statements is your concerned about online } \\
\text { purchases? }\end{array}$ & $\begin{array}{l}\text { Frequency } \\
\text { (N=154) }\end{array}$ & $\%$ \\
\hline I worry about getting scammed by the seller & 131 & 84.0 \\
\hline I worry about product quality & 128 & 82.1 \\
\hline I worry about payment security & 110 & 70.5 \\
\hline I worry about my credit card number being stolen on the internet & 92 & 59.0 \\
\hline I worry about personal privacy & 89 & 57.1 \\
\hline
\end{tabular}

When respondents were asked about their concerns towards online purchases (Table 3), the top two statements stated by them were they worry about getting scammed by the seller (84\%) and they also worry about product quality (82.1\%). These findings may be due to their concerns about the item would not perform as expected since they are unable to physically examine products before buying online (Dhanapal et al., 2015; M. M. Kumar \& Sobha, 2015). This concern is referred to as performance risk which is potentially causes the buyer to making loss if they receive product that fails to perform as expected or they may receive a product that the actual features does not match the ones mentioned on the website (Nepomuceno, Laroche, \& Richard, 2014). This proves that nononline shoppers are more vigilant about the money losses as compared with online shoppers (Mutum; \& Ghazali, 2006).

The respondents also worry about payment security (70.5\%). This means that non-online shoppers are concerned if they have made payments to the vendor, but the goods may not be delivered. In addition, the respondents also worry about their credit card number being stolen on the internet (59\%) and they also worry about personal privacy (57.1\%). This study shows that respondents are concerned about their online security. Some researchers believe that consumers who are concerned about privacy security (such as their full name, address and phone number) are more easily dealt with than consumers who are concerned with security of payments. Online vendors only need to convince the consumers about the security of their personal data. Instead, consumers will be concerned about the credit card payment because they need to enter their own credit card number and password on the website. In sum, those who believe that online transactions are susceptible to frauds and thus not secure are less likely to purchase online (V. Kumar \& Dange, 2014; Nepomuceno et al., 2014).

Table 4: Privacy Concerns of Non-Online Shoppers

\begin{tabular}{|l|l|l|l|}
\hline \multirow{2}{*}{$\begin{array}{l}\text { How do privacy concerns prevent you from buying } \\
\text { products online? }\end{array}$} & \multicolumn{3}{|c|}{ Frequency (N=156) } \\
\cline { 2 - 4 } & $\begin{array}{l}\text { Male } \\
(\mathrm{N}=121)\end{array}$ & $\begin{array}{l}\text { Female } \\
(\mathrm{N}=35)\end{array}$ & $\begin{array}{l}\text { Total } \\
(\mathrm{N}=154)\end{array}$ \\
\hline Always & 33 & 12 & 45 \\
\hline Most of the time & 38 & 10 & 48 \\
\hline About half the time & 18 & 5 & 23 \\
\hline Once in a while & 28 & 7 & 35 \\
\hline Never & 3 & 0 & 3 \\
\hline
\end{tabular}


INTERNATIONAL JOURNAL OF ACADEMIC RESEARCH IN BUSINESS AND SOCIAL SCIENCES Vol. 8, No. 9, Sept. 2018, E-ISSN: 2222-6990 @ 2018 HRMARS

Table 4 shows the privacy concern prevent respondents form buying products online. Respondents place privacy concerns to make online purchases for "most of the time" and "always" are represented by $60.4 \%$ respondents. The results also show that non-online shoppers' concern about their privacy is of frequency. This study reveals that both genders are highly concerned about the privacy and security issues and have an impact on their intention to purchase through online.

\section{Implications and Conclusions}

By analyzing the concerns related to shopping online, this study attempts to investigate the factors that become barriers to the non-online shoppers to purchase online. A clear understanding of the consumers' concerns, needs and wants is crucial for improving marketing strategies for internet stores. The major findings of this study emphasize the importance of managing negative online customer perceptions. The results show the main reason respondents do not prefer to shop online is that they are concerned about the quality of a product. Hence, online vendors may use the findings of this study to improve their online store designs, streamline their online business operations, and improve their customer support services.

In addition to concern towards quality of a product, this study found that non-online shoppers are also concerned toward privacy security. Risk perceptions regarding online purchase/internet privacy and security have been identified as issues for online shoppers specifically for students in higher learning education. It is commendable then that online sellers make the efforts to display privacy policy information to leverage on privacy protection as their selling point (Tsai, Egelman, Cranor, \& Acquisti, 2011). It is important for online retailers to understand the motivations and barriers to online purchase, especially in enhancing their digital marketing strategy. The effectiveness of using the digital marketing channels like company websites, mobile apps and social media company pages will help to reach potential customers, also to develop customers relationship (Chaffey, 2018). Otherwise, online vendors must keep track of fast moving digital marketing to craft relevant strategy moving forward.

Furthermore, the findings of this study not only contribute to the enrichment of knowledge for online vendors but also benefited traditional sellers, perhaps for traditional retailers is to create with the strategy and meet the changing expectations of consumers. The current study assures that although most university students love to shop online, shopping at the real stores still has its own fans. Furthermore, stress-filled life on campus causes university students to search for space and opportunity to entertain themselves with their friends on the weekend causing shopping in the real store to be a fun experience. It is clear that despite competition with online vendors, the opportunity for the traditional sellers to sell their products at the real stores remains. Nevertheless, when it comes to customers experience, traditional retailers can create unique experience by express the brand and product in a creative way. It will encourage customers to visit the stores frequently. Traditional sellers may provide the comfortable shopping environment and offer more attractive after-sale services, not offered by online vendors. Since many non-online shoppers reluctant to shop online due to doubts about the quality of the items to be bought, this group should be very cautious and prefer to interact with salespeople before making a purchase decision. Accordingly, the traditional retailers should improve the behaviors and skills of their salespersons to convince their customers.

In sum, the findings of this study are consistent with previous research findings and help in bridging research gaps that has been identified. This is thought to have made an important 
INTERNATIONAL JOURNAL OF ACADEMIC RESEARCH IN BUSINESS AND SOCIAL SCIENCES

Vol. 8, No. 9, Sept. 2018, E-ISSN: 2222-6990 @ 2018 HRMARS

contribution to enhance and extend our understanding about the reasons for non-shoppers prefer traditional shopping and the reasons they are reluctant to purchase online. In conclusion, the contributions reported from this study will certainly overcome some shortcomings in the current literature.

\section{Corresponding Author}

Nurul Nadia Abd Aziz

Faculty of Business and Management, Universiti Teknologi MARA Cawangan Pahang Kampus Raub, 27600 Raub, Pahang, Malaysia

Email: nurul_nadia@pahang.uitm.edu.my

\section{References}

Akroush, M. N., \& Al-Debei, M. M. (2015). An integrated model of factors affecting consumer attitudes towards online shopping. Business Process Management Journal, 21(6), 1353-1376.

Al-Debei, M. M., Akroush, M. N., \& Ashouri, M. I. (2015). Consumer attitudes towards online shopping: The effects of trust, perceived benefits, and perceived web quality. Internet Research, 25(5), 707-733.

Al-maghrabi, T., Dennis, C., \& Halliday, S. V. (2011). Antecedents of continuance intentions towards e-shopping : the case of Saudi Arabia. Journal of Enterprise Information Management, 24(1), 85111.

Ang, L., \& Lee, B. (2002). Trust , choice and online shopping. Fourth Australasian Services Research Workshop (pp. 7-17). Victoria.

Aziz, N. N. A., \& Wahid, N. A. (2017). Understanding customer behaviour towards online shopping. In 2nd Business Management and Computing Research Colloquium (pp. 164-168).

Aziz, N. N. A., \& Wahid, N. A. (2018). Factors influencing online purchase intention among university students. International Journal of Academic Research in Business and Social Sciences, 8(7), 702717.

Badari, S. A. Z., \& Hashim, A. H. (2015). Amalan pembelian secara atas talian dan faktor-faktor mempengaruhinya. In 19th MACFEA National Seminar 2015 (pp. 764-770).

Bay, D., Cook, G. L., Grubisic, J., \& Nikitkov, A. (2014). Identifying fraud in online auctions: a case study. Accounting Perspectives, 13(4), 283-299. http://doi.org/10.1111/1911-3838.12033

Bilgihan, A. (2016). Gen Y customer loyalty in online shopping: An integrated model of trust, user experience and branding. Computers in Human Behavior, 61, 103-113.

Chakraborty, R., Lee, J., Bagchi-Sen, S., Upadhyaya, S., \& Raghav Rao, H. (2016). Online shopping intention in the context of data breach in online retail stores: An examination of older and younger adults. Decision Support Systems, 83, 47-56.

Chen, Y., Yan, X., Fan, W., \& Gordon, M. (2015). The joint moderating role of trust propensity and gender on consumers' online shopping behavior. Computers in Human Behavior, 43, 272-283.

Cheung, C. M., \& Lee, M. K. (2003). An integrative model of consumer trust in internet shopping. In ECIS 2003 Proceedings.

Dai, H., Harried, P., \& Salam, A. F. (2011). Antecedents of online service Quality, commitment and 
INTERNATIONAL JOURNAL OF ACADEMIC RESEARCH IN BUSINESS AND SOCIAL SCIENCES

Vol. 8, No. 9, Sept. 2018, E-ISSN: 2222-6990 @ 2018 HRMARS

loyalty. Journal of Computer Information Systems, 52(2), 1-11.

Dhanapal, S., Vashu, D., \& Subramaniam, T. (2015). Perceptions on the challenges of online purchasing: A study from "baby boomers", generation " $X$ " and generation " $Y$ " point of views. Contaduria Y Administracion, 60, 107-132.

Ensing, D. (2014). How marketers can determine true customer experience from review-based websites. Marketing Insights, 26(1), 31-33. Retrieved from http://search.ebscohost.com/login.aspx?direct=true\&db=heh\&AN=102419549\&lang=ptbr\&site=eds-live\&scope=site

Faqih, K. M. S. (2016). An empirical analysis of factors predicting the behavioral intention to adopt Internet shopping technology among non-shoppers in a developing country context: Does gender matter? Journal of Retailing and Consumer Services, 30, 140-164.

George, O. J., Ogunkoya, O. A., Lasisi, J. O., \& Elumah, L. O. (2015). Risk and trust in online shopping : experience from Nigeria. International Journal of African and Asian Studies, 11, 71-78.

Hernández, B., Jiménez, J., \& José Martín, M. (2011). Age, gender and income: do they really moderate online shopping behaviour? Online Information Review, 35(1), 113-133.

Huseynov, F., \& Yildirim, S. O. (2016). Internet users ' attitudes toward business-to-consumer online shopping : A survey. Information Development, 32(3), 452-465.

Irshad, S. (2016). Mediating role of customer value between innovative self service technology (ISST) factors and online repurchase intention. Journal of Internet Banking and Commerce, 21(2).

Jadhav, V., \& Khanna, M. (2016). Factors influencing online buying behavior of college students : a qualitative analysis. The Qualitative Report 2016, 21(1), 1-15.

Katawetawaraks, C., \& Wang, C. L. (2011). Online shopper behavior: influences of online shopping decision. Asian Journal of Business Research, 1(2).

Kumar, M. (2016). Consumer behavior and satisfaction in e-commerce: a comparative study based on online shopping of some electronic gadgets. International Journal of Research in Commerce and Management, 7, 62-67.

Kumar, M. M., \& Sobha, P. G. . (2015). Online shopping behavior among higher education students with special reference to Palakkad ,. IJARIIE, 1(5), 507-514.

Kumar, P., \& Bajaj, R. (2016). Dimensions of perceived risk among students of high educational institutes towards online shopping in Punjab. Journal of Internet Banking and Commerce, 21(Special Issue 5).

Kumar, V., \& Dange, U. (2014). A study on perceived risk in online shopping of youth in Pune : A factor analysis. Acme Intellects International Journal of Research in Management, Social Sciences \& Technology, 8(8), 1-9.

Lian, J. W., \& Yen, D. C. (2013). To buy or not to buy experience goods online: Perspective of innovation adoption barriers. Computers in Human Behavior, 29(3), 665-672.

Lim, Y. J., Osman, A., Salahuddin, S. N., Romle, A. R., \& Abdullah, S. (2016). Factors influencing online shopping behavior: the mediating role of purchase intention. Procedia Economics and Finance, 35(October 2015), 401-410.

Ling, L. P., \& Yazdanifard, R. (2014). Does gender play a role in online consumer behavior? Global Journal of Management and Business Research: E Marketing, 14(7), 1-9.

Massad, V. J., \& Berardelli, K. (2016). The roles of bounded rationality and ethical self-efficacy in online shopping orientation. Academy of Marketing Studies Journal, 20(3), 26-37. 
INTERNATIONAL JOURNAL OF ACADEMIC RESEARCH IN BUSINESS AND SOCIAL SCIENCES

Vol. 8, No. 9, Sept. 2018, E-ISSN: 2222-6990 @ 2018 HRMARS

Mittal, A. (2013). E-commerce: It 's Impact on consumer behavior. Global Journal of Management and Business Studies, 3(2), 131-138.

Monsuwé, T. P. y, Dellaert, B. G. C., \& Ruyter, K. de. (2004). What drives consumers to shop online? A literature review. International Journal of Service Industry Management, 15(1), 102-121.

Mutum;, D., \& Ghazali, E. (2006). Online shoppers vs non-shoppers: a lifestyle study of Malaysian internet users. In International Proceedings of AGBA 3rd World Congress (Vol. 3, pp. 4-6).

Narayanan, M., Koo, B., \& Cozzarin, B. P. (2012). Fear of fraud and Internet purchasing. Applied Economics Letters, 19(0), 1615-1619.

Nazir, S., Tayyab, A., Sajid, A., Ur Rashid, H., \& Javed, I. (2012). How online shopping is affecting consumers buying behavior in Pakistan? IJCSI International Journal of Computer Science, 9(3), 486-495.

Nepomuceno, M. V., Laroche, M., \& Richard, M. O. (2014). How to reduce perceived risk when buying online: The interactions between intangibility, product knowledge, brand familiarity, privacy and security concerns. Journal of Retailing and Consumer Services, 21(4), 619-629.

Nuryakin, \& Farida, N. (2016). Effects of convenience online shopping and satisfaction on repeatpurchase intention among students of higher institutions in Indonesia. Journal of Internet Banking and Commerce, 21(2).

Nwaizugbo, I. C., \& Ifeanyichukwu, C. D. (2016). Understanding consumers' behaviour towards online shopping: A study of online shoppers in Anambra State. International Journal of Sales, Retailing and Marketing, 5(2), 28-38.

Saidi, N. (2016, May). Bijak belanja pada musim perayaan. Utusan Online.

Sharma, A. K. (2016). Factors influencing youngsters' behavior towards online shopping in Vellore district of Tamilnadu. Journal of Internet Banking and Commerce, 21(November).

Topalo, C. (2012). Consumer motivation and concern factors. Asian Academy of Management Journal, 17(2), 1-19.

Tsai, J. Y., Egelman, S., Cranor, L., \& Acquisti, A. (2011). The effect of online privacy information on purchasing behavior: an experimental study. Information Systems Research, 22(2), 254-268.

Van Der Meulen, N. S. (2013). You've been warned: Consumer liability in Internet banking fraud. Computer Law and Security Review, 29(6), 713-718.

Violani, L. S. (2016). The influence of consumer decision-making styles towards purchasing behavior: a case study of online shopping in Jakarta, Indonesia. International Journal of Management, Accounting and EconomicsOnline) International Journal of Management, Accounting and Economics, 3(5), 296-305. Retrieved from www.ijmae.com 